\title{
The clearing and partial excavation of the cairns at Balnuaran of Clava, Inverness-shire, by Miss Kathleen Kennedy, 1930-31
}

\author{
G J Barclay*
}

\section{ABSTRACT}

Miss Kennedy's brief summary report is transcribed. Contemporary drawings and photographs are reproduced and set in context. There is a brief discussion on the tidying and reconstruction of the monument and of the significance of Miss Kennedy's results.

\section{INTRODUCTION}

The three cairns at Balnuaran of Clava are among the best known prehistoric monuments in northern Britain. The Clava cairns, including those at Balnuaran, were admirably described by Henshall (1963) who also dealt lucidly with the history of study of the sites. The only modern excavations published are those undertaken by Piggott in the early 1950s, as part of a research programme sponsored by this Society (Piggott 1956). The reports of the excavations at Newton of Petty and Raigmore, on a Clava cairn and a possible Clava cairn with Grooved Ware antecedents respectively, both undertaken in the early 1970 s, have not yet been published.

The cairns at Balnuaran have been in the care of the state since 1925. This note places for the first time in the public domain the account of the clearing and limited excavation of the cairns in 1930 and 1931, together with some of the photographs and drawings of the work then undertaken. The documents relating to the work, some of which are transcribed below, are on Ministry of Works file SC 22913/2A, now in the Scottish Record Office. The photographs taken in the 1920s and 1930s are now lodged in the National Monuments Record for Scotland and the original Ministry of Works drawings are still part of the HBM working collection.

The Balnuaran cairns comprise two Clava passage-graves, a Clava ring-cairn, and a small heavily-kerbed burial enclosure. Shortly after the cairns came into care it was decided that work would need to be done to clear vegetation and collapsed stone from the site to make it safe and accessible for visitors.

\section{THE ORGANIZATION OF THE WORK}

On 3 July 1930 J S Richardson, then Inspector of Ancient Monuments for Scotland, wrote to the Chief Inspector of Ancient Monuments in London, Mr C R Peers, stating that it had been decided $\therefore$. to clear the debris and the fallen stones from the passages and chambers of the Cairns, work which for obvious reasons demands careful supervision.'

\footnotetext{
${ }^{*}$ Inspectorate of Ancient Monuments, Historic Buildings \& Monuments, 20 Brandon Street, Edinburgh
} 
Professor Childe recommended one of his graduates for the task. On 13 August $1930 \mathrm{Mr}$ Seagrave of the Office of Works in London wrote to Mr Penson at the Treasury for permission to appoint Miss Catherine [sic] Kennedy. After trying to persuade the Office of Works to find someone on the staff of one of the national museums to do the work for nothing (no-one could be spared) the Treasury agreed to the employment of Miss Kennedy.

THE 1930 SEASON

The work of 1930 was not described in detail on the file. On 30 August Miss Kennedy wrote to Mr Richardson:

'. . the chambers cleared out and the most obstreperous trees cut down', and that

'Miss Mitchell [our late fellow Dr Margaret Stewart] was with me for a while and we made a rough survey of the cairns'.

A postscript to the letter, dated 1 September, describes finding the two parts of a cup-marked stone in one cairn (unspecified) and its placing for safe-keeping with 'Mrs Johnston'. Mr Richardson reported to the Chief Inspector on 11 September that the work had been finished on 30 August and that he, with Miss Kennedy, had visited the site on 5 September. He arranged a further two weeks' work, to be undertaken after the harvest, when the men from the local farm would once again be available to provide muscle. He attached a number of photographs to the file to show what had been done. The prints reproduced here do not have the sepia-stained charm of the originals but the character of the monuments so familiar today is clear.

On 24 September Miss Kennedy wrote to Miss Simpson, the Assistant Inspector, about the extension of the work. She took the opportunity to check what her instructions were (they had apparently been scribbled on Mr Richardson's railway guide):

(1) Cut marked trees

(2) Clear bushes

(3) Remove large stones from chambers

(4) Push back small stones from edges of cairn

(5) Turf flat slab at end of passage of east cairn

(6) Scrape moss from stones

(7) Clear small circles

(8) Clear middle cairn.'

There was no detailed description of the work.

\section{THE 1931 SEASON}

In June and July 1931 arrangements were set in hand for a second season of work, to be supervised by Miss Kennedy, the work to be the responsibility of the Assistant Inspector, Miss Simpson. Work commenced on 31 August. An undated paper, inserted on file before one dated 17 September 1931, described the work in limited detail. As the information contained in it is duplicated and expanded in the paper dated 7 October it is not transcribed here.

In an undated letter (from internal evidence, dating from before 18 September) Miss Kennedy reported that the western cairn's kerb was now complete, the gaps being

'. . f filled by fallen kerb stones unearthed beneath the cairn,'

and that

'We are making a very elegant job of the west cairn, detaching the buried kerbstones and levering them into position.' 
Miss Kennedy had suggested excavating some of the chamber deposits in a letter of 22 September. On 25 September Mr Richardson sent a telegram 'Richardson visiting Clava Monday. Noted you are remaining on work. Do not excavate.'

Excavation seems to have proceeded after discussion, not recorded, for on October 2 Miss Kennedy wrote to Miss Simpson.

'I have investigated the floors of the east and west cairns. The clayey layer we noted in Cairn A (the west cairn) was laid over the floor. Someone has dug (fairly recently) a hole about 4' square in the centre, which has of course broken the layer. I have stripped the black earth from the top, laying bare the floor, because I was under the impression that someone was coming on Saturday to look at it. It is now ready to be sanded. The clayey substance varies in colour from whitish-yellow to this dark colour of which I am enclosing a sample. The sample is cut from the very surface of the clayey layer. There was a great deal of charcoal in the (?) wall where the dark stuff was found (charcoal from some picnic fires presumably) that may have discoloured the clay.

The east cairn, C, showed no trace of the clay layer. . . .'

Miss Simpson replied on 3 October, telling Miss Kennedy, in response to questions, not to excavate the floor of the ring-cairn, and to cover the clay layer in Cairn A with black earth.

On 7 October Miss Kennedy submitted a report of her work, in manuscript. A typed transcript and further photographs were placed on file.

' 1931

CAIRNS AT BALNUARAN OF CLAVA, STRATHNAIRN

Work was begun with three men on the 31st of August. Two additional men were engaged from the 19th of September to the 2nd of October.

CAIRN A [Balnuaran South-west]

The west cairn was stripped of whins, raspberry plants and other vegetation. Loose stones were

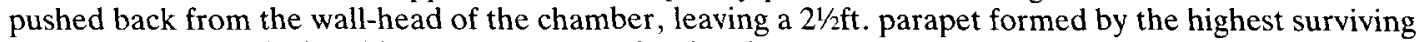
course of the wall. Slabs which had fallen into the chamber were replaced on the walls. Depressions in the Cairn (caused by the removal of cartloads of stones by road workers) were filled in, and the contour of the cairn restored.

A kerb of large boulders, closely set to confine the cairn, was in most places visible, though some had been submerged in falls of stones. A cutting was made from one kerbstone to the depression surrounding the cairn. It was found that a packing of stones and soil about $18^{\prime \prime}$ deep had been laid against the outer face of the kerb. The distance from the kerb to the outer edge of the packing was about 10 feet. It was easy to distinguish between the loose stones fallen from the cairn and the original packing: the latter was composed mostly of small water rolled pebbles with an admixture of shells. Larger stones were used on the outer edges.

Turf was removed from the packing and the fallen stones were replaced on the cairn. Almost the whole kerb was revealed. One or two stones had collapsed and were reared into position. The stones on the east side were much smaller than those by the entrance.

A second cutting was made to show the face of the only slab set in the kerb [illus 15]. It faced $111^{\circ} \mathrm{E}$. of $\mathrm{N}$, and was about $3 \mathrm{ft}$ square and $1^{\prime} 9^{\prime \prime}$ in thickness. The outer face was covered with cup-marks which seemed to be made in sets of three.

The depression round the cairn gave rise to a suggestion that it had been surrounded by a ditch. A continuation of the first cutting disproved the theory: the soil in the cutting was mingled with natural boulders. The sequence of layers was black earth, red sand and gravel. A curious band $2 \frac{1}{2} \mathrm{ft}$. long of clayey substance was noted in the cutting.

Lastly, the floor of the chamber was investigated [illus 2]. A cutting was made on the south of the entrance. The first upright, a large rectangular slab had its foundation $2 \mathrm{ft}$. lower than its neighbour. The latter rested on a packing of stones, slates and soil. The first upright was bedded in clay and packed with round and split stones. The fourth upright was found to be set 1' $4^{\prime \prime}$ lower than its neighbours, and indeed there was no common level for the foundations of the stones. No other case of bedding in clay was noted. A layer of black earth, about 6 " deep, having been removed from the floor a layer of clayey material was 


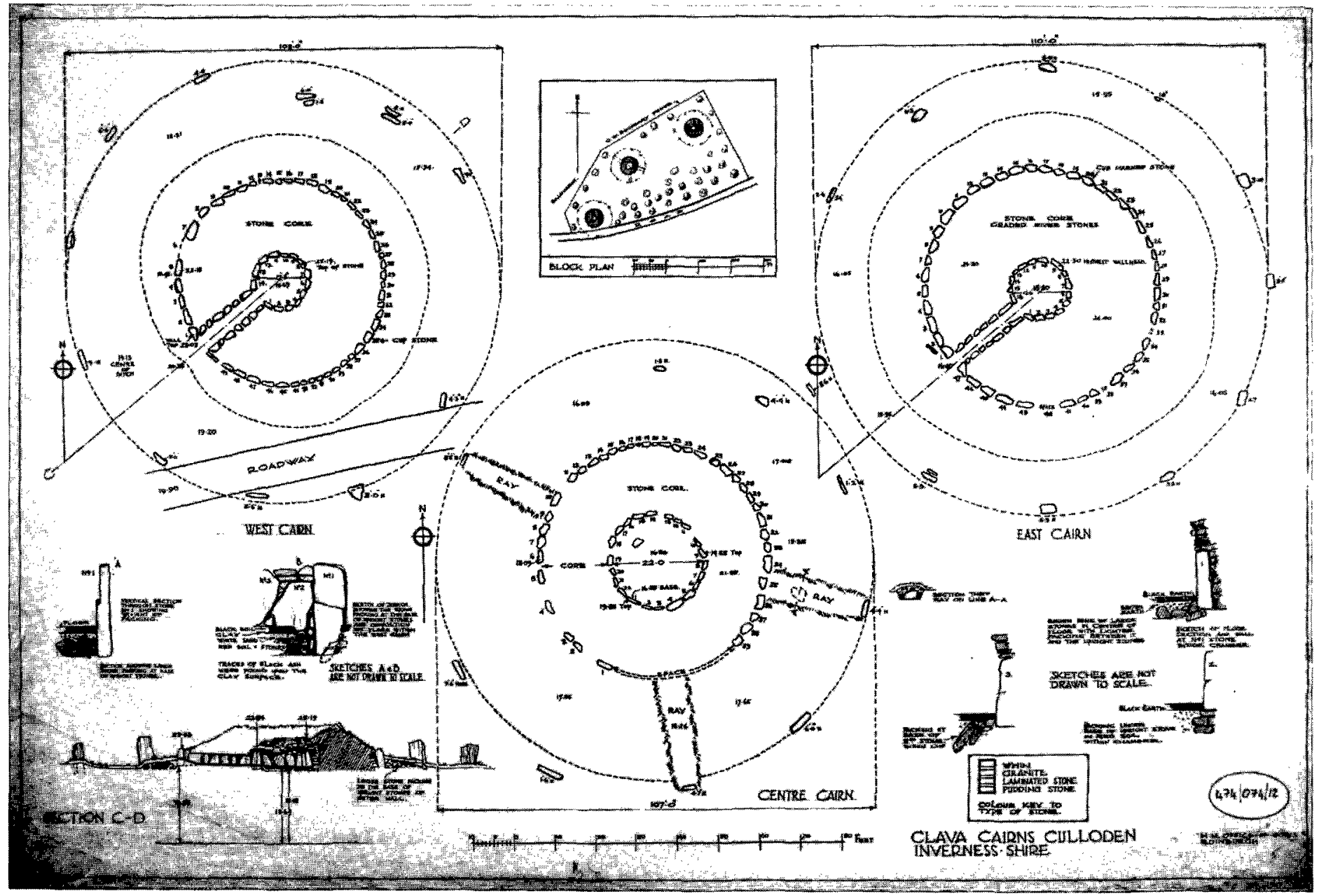

Illus 1 Plan of the Balnuaran of Clava cairns, showing the approximate location of Miss Kennedy's sections, possible field banks, and cup-marked stones. HBM drawing 474/074/12 


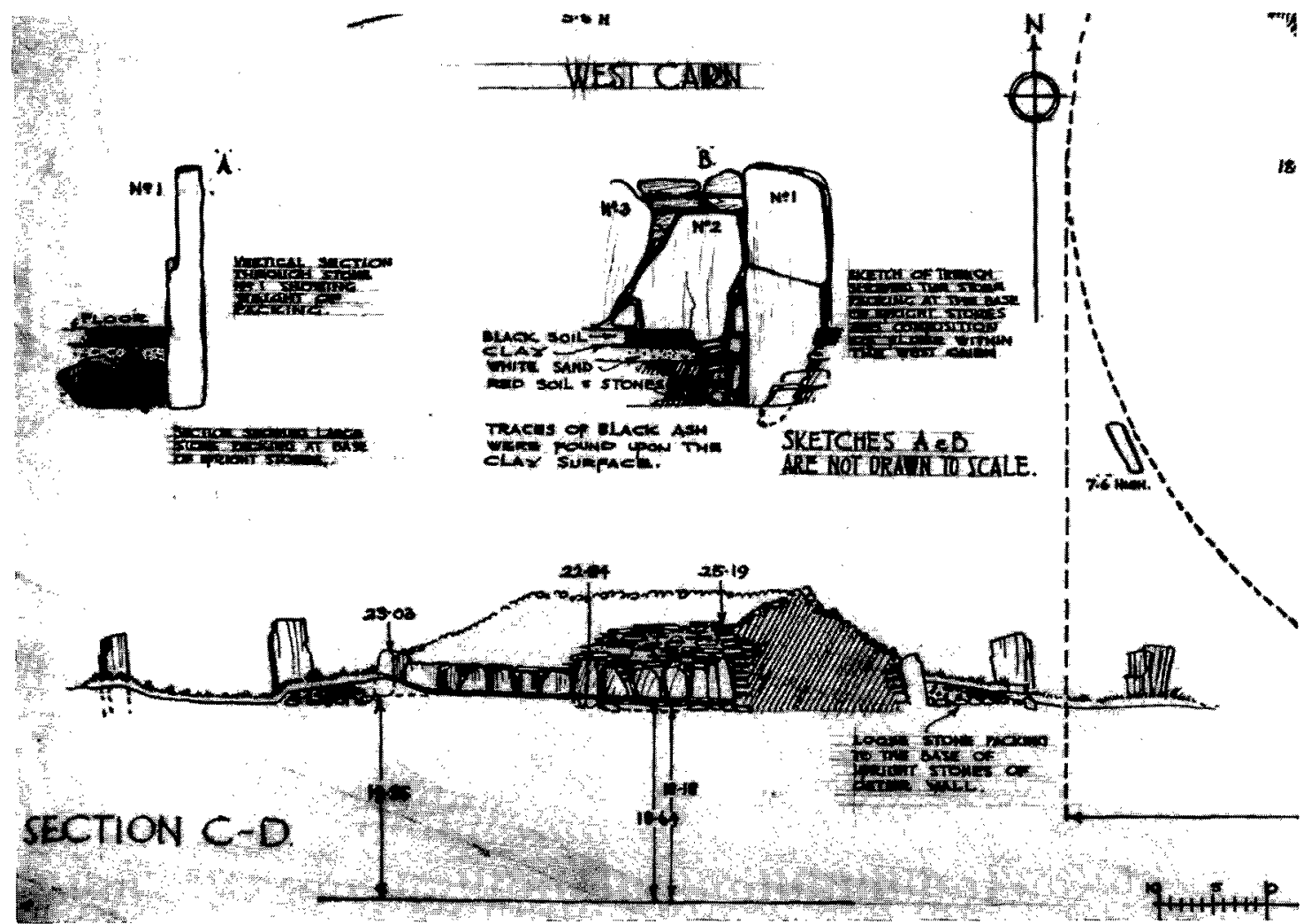

ILLus 2 Extract from HBM drawing 474/074/12 showing a section of the south-west cairn and (not to scale) sections through the central chamber

revealed. It had evidently been laid down over the whole floor. The colour varied from yellowish-white to dark grey. The depth varied from $2^{\prime \prime}$ to about $4 "$. The clayey layer rested on red sand.

The clay was broken by a hole about $4 \frac{1 / 2}{\mathrm{ft}}$. square in the middle of the floor. It had been recently disturbed, for the soil had not yet filled in the interstices between the stones. A more ancient disturbance is related in 'Moray Floods' by Sir Thomas Dick Lauder, who gives an account of an excavation in 1828 or 1829 by Mrs Campbell of Kilravock Castle. She took from the centre of the floor and some $18^{\prime \prime}$ below it, the fragments of two urns [not located]. These contained, and were surounded by, a quantity of calcined bones. They were 'enclosed in a portion of clay distinct from the natural soil'.

\section{CAIRN B [Balnuaran Centre]}

The three rays on this cairn were uncovered, and cuttings dug across two of them. They were found to be causeways of stone, six feet wide, definitely laid with a kerbing of flat stones, to a height of about $18^{\prime \prime}$ above the ground level. A large boulder was found under a ray on the south side.

\section{CAIRN C [Balnuaran North-east]}

The east cairn, being of similar form to the west, was dealt with in the same way. The vegetation was removed, and the wall-head cleared. The kerbstones in $\mathrm{C}$ are much larger than those in $\mathrm{A}$, and the cairn was more dilapidated. The majority of the boulders were thrust out of position, some buried altogether and some lost. The remaining boulders were cleared and levered into position.

In three places a large slab was found lying behind or above the kerbstones (one measures $3^{\prime} 9^{\prime \prime} \times 2^{\prime} 9^{\prime \prime} \times 1^{\prime} 4^{\prime \prime}$ thick). These suggest cists or entrances, whether false or real.

Two cup-marked stones were found on the east side. One was a slab about 4 " thick and was found 


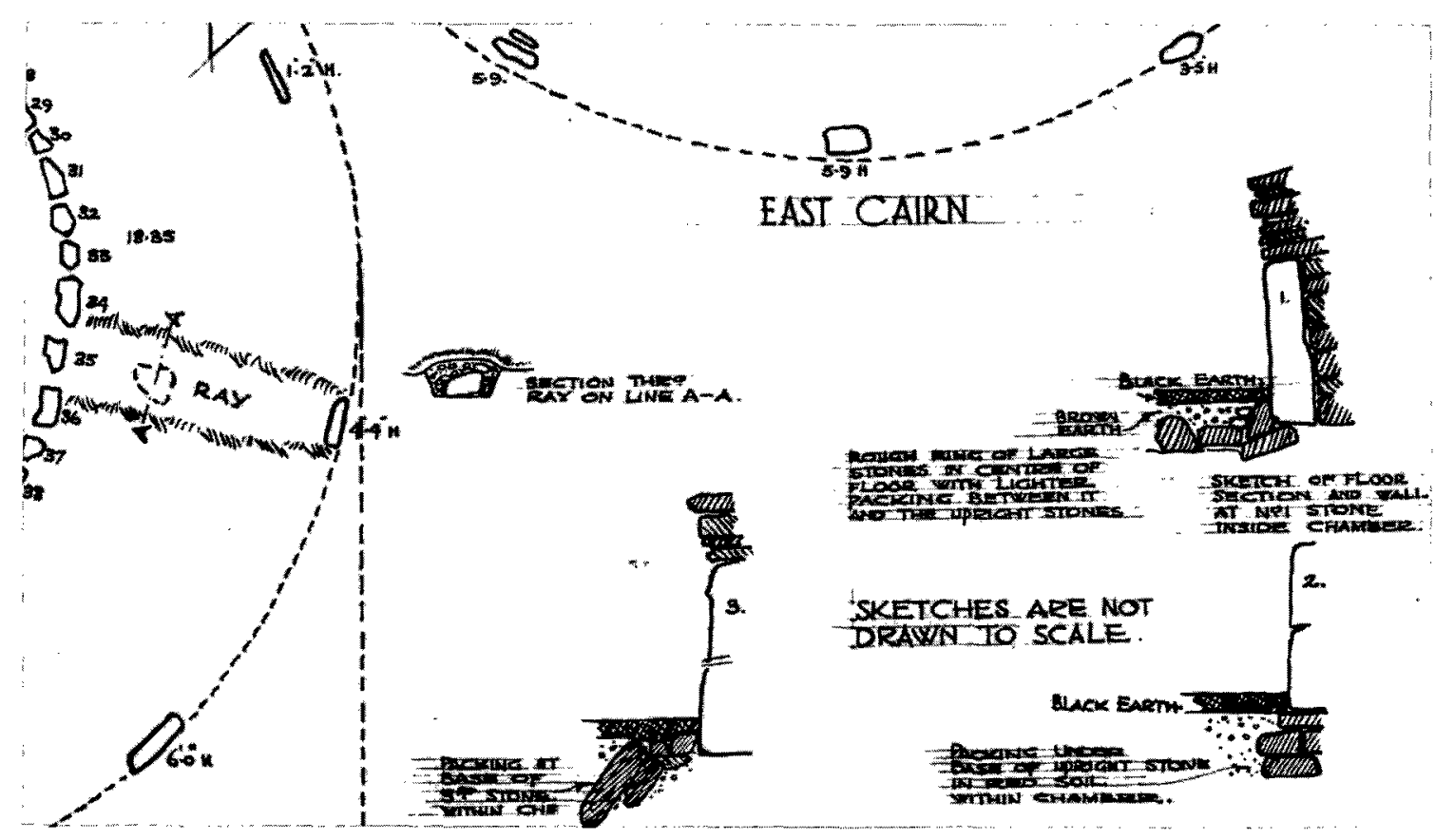

ILLus 3 Extract from HBM drawing 474/074/12 showing sections through the central chamber of the north-east cairn. There is also a section across one of the rays of the ring-cairn

under the packing. The second was a boulder measuring $3^{\prime} 6^{\prime \prime} \times 3^{\prime}$ in height and $1^{\prime} 3^{\prime \prime}$ in thickness, and seemed to be one of the kerbstones. When raised it faced $15^{\circ} \mathrm{E}$. of $\mathrm{N}$. The outer face was covered with cups, rings, channels and surrounded by a groove.

A flake of flint without secondary working, and a bone with tooth-marks were discovered near the cup-marked boulders in a crevice beneath the $3^{\prime} 9^{\prime \prime}$ slab.

The floor of the chamber was also investigated [illus 3], but it revealed no trace of clay, nor any attempt to set the entrance stones deeper than the rest. In the undisturbed parts a $5^{\prime \prime}$ layer of black earth rested on red sand. The uprights were supported by an inner ring of stones under the floor; the space between the ring and the wall being packed with small stones. On the north side, the upright by the entrance was not packed at all and almost rested on the floor. A large stone measuring $4^{\prime} \times 3^{\prime} \times 1^{\prime}$ lay under the floor against the 2 nd and 3rd uprights.

In the east cairn (C) the foundations of the kerbstones seem to be raised above the level of the chamber floor and ground outside. In the west cairn (A) they are on a level with the chamber floor.

OCTOBER 3rd

Photographs and levels having been taken, turf was replaced and trenches filled in. One section of the floor in Cairn A. was left untouched and the cutting opposite the cup-marked stone left open. All the east side of Cairn C. was left exposed.

Three men were left on the spot to repair walls and fences, cut trees, clear overgrown stones and plant ferns on the loose cairn stones as a binding. After later inspection, they are to fill in trenches and returf Cairn C.

$$
\text { (Intld.) M.K.K.' }
$$

Miss Kennedy wrote on 22 October, with plans on which (except for the eastern cairn) the stones were numbered; a list of the stones which had fallen and been re-erected was attached. Although the list cannot now be located, the information had been transcribed on to drawing number 


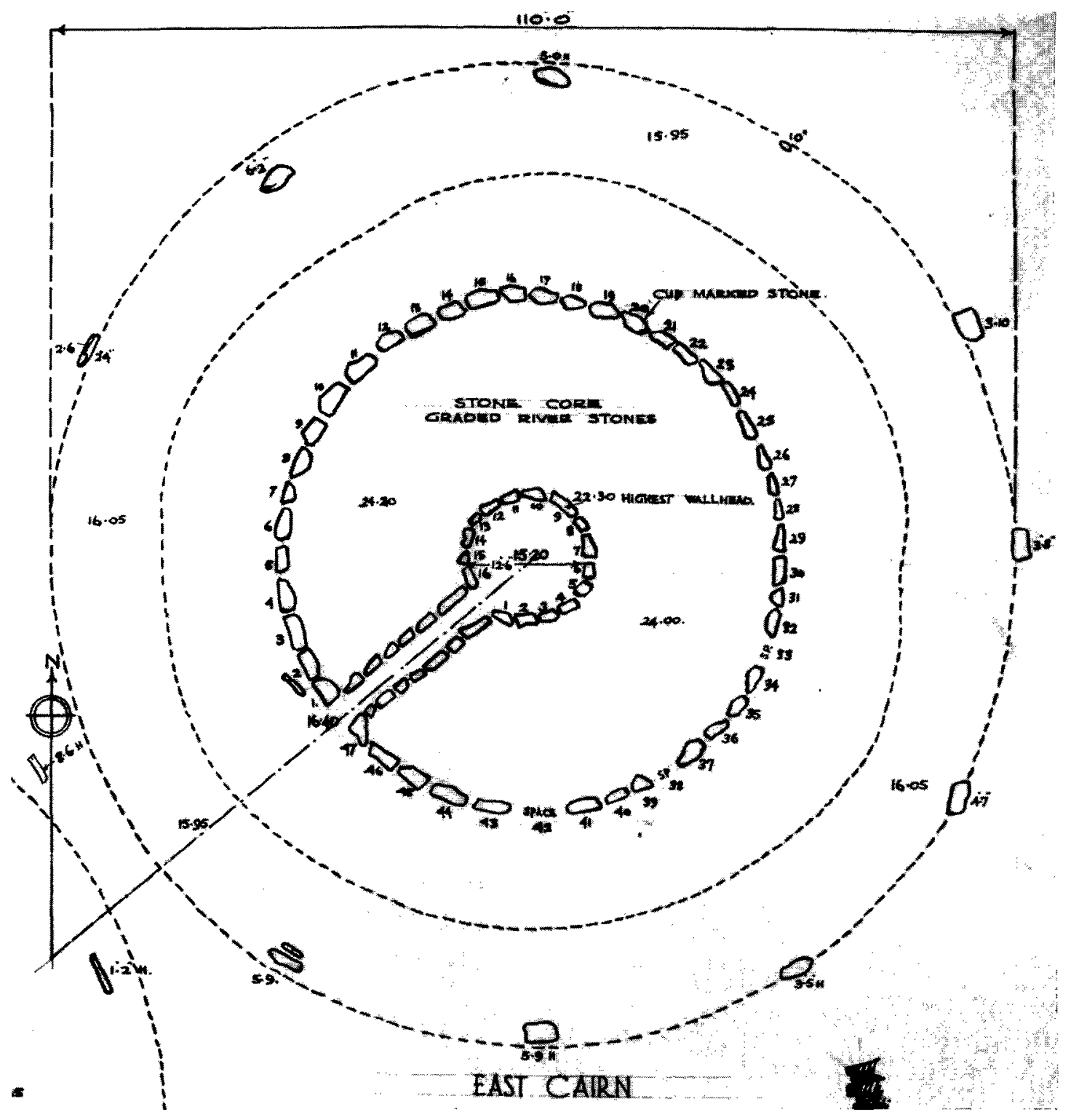

ILlus 4 Extract from HBM drawing 474/074/12 showing the plan of the north-east cairn.

474/074/15 in the HBM archive. The stones which had fallen in the kerb of the north-east cairn were: $4,5,6,10,11,15,18,19,20,21,22,23,24,29,31,34,35,36$ and 40 (illus 4 ). In the kerb of the southwest cairn stones 8,9 and 45 were recumbent (illus 5).

Mention is made on the file of a survey and drawing of the sites in 1931; the drawings $474 / 074 / 12,13,14$ and 15 are the result of that work. 


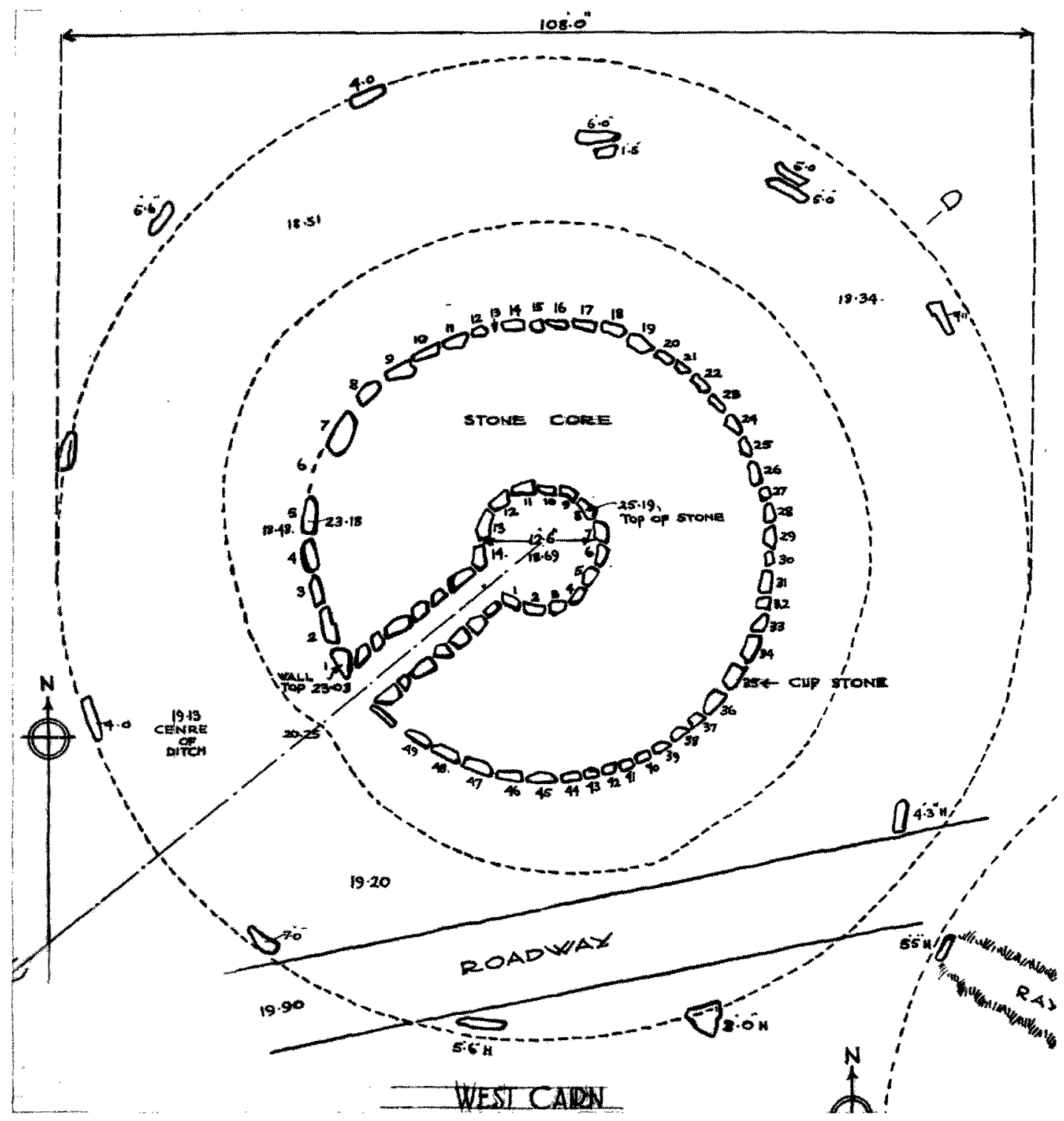

ILLUS 5 Extract from HBM drawing 474/074/12 showing the plan of the south-west cairn

THE 1930s WORK, NEW WORK AND OUR UNDERSTANDING OF THE CLAVA GROUP

THE RECONSTRUCTION

It is clear from Miss Kennedy's reports and letters and from the photographs on file that some parts of the cairns were disturbed to a considerable extent during the work. We are fortunate in having a number of photographs, probably taken by Mr Richardson in 1924, at an early stage in the negotiations to take the site into care, with which to compare the during and after shots of 1930/1. 


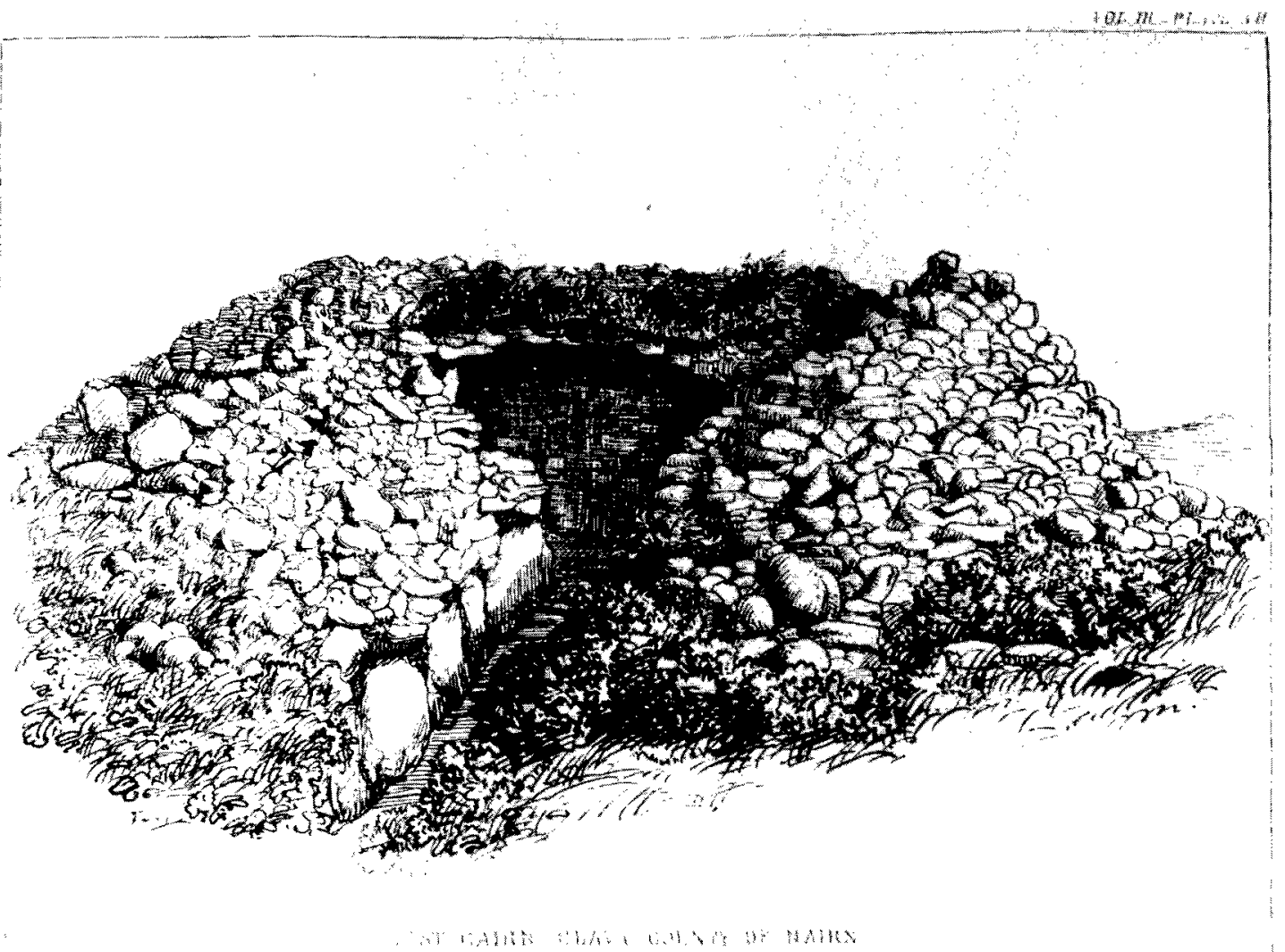

ILlus 6 Drawing of the north-east cairn prepared by Rev Burnett Stewart for Innes 1860

There are also the fine ink drawings prepared by the Rev Burnett Stewart (Innes 1860, 48-9), which show the extent to which the corbelled upper wall of the north-east cairn chamber had been removed in or before 1930 (illus 6).

The sequence of three plates in illus 7,8 and 9 shows the north-east cairn in 1924, probably in 1930 and probably in 1931, respectively. The increasing prominence of the kerb is clear. It is clear that the prominent flat tops of the ramps of stone surrounding the kerb are the result of selective removal of material and that the kerbs were originally less prominent.

The two prints in illus 10 and 11 are taken from Balnuaran north-east, past the ring-cairn to the south-west cairn, and the south-west cairn in 1930/1.

The two prints in illus 12 and 13 show the comparable progress of Balnuraran south-west from 1924 to 1931 . The stages of raising the cairn material to a higher level while moving it back from the edge of the chamber can be seen very clearly in the area above the wall at the back of the chamber, to the right of the axis of the passage. Over $0.3 \mathrm{~m}$ has been added and the profile of the cairn has been very much smoothed. 


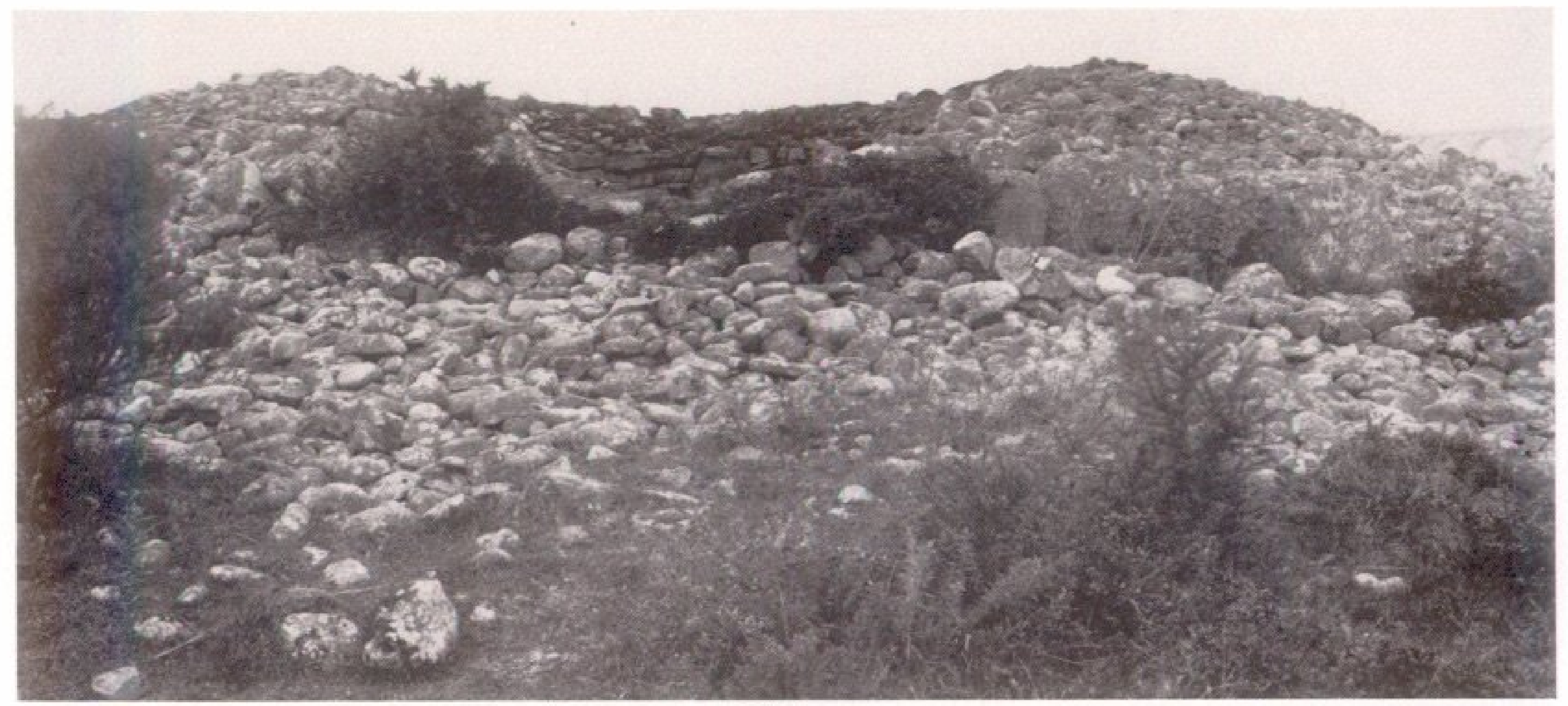

ILLus 7 The north-east cairn in 1924 (NMRS no A48005)

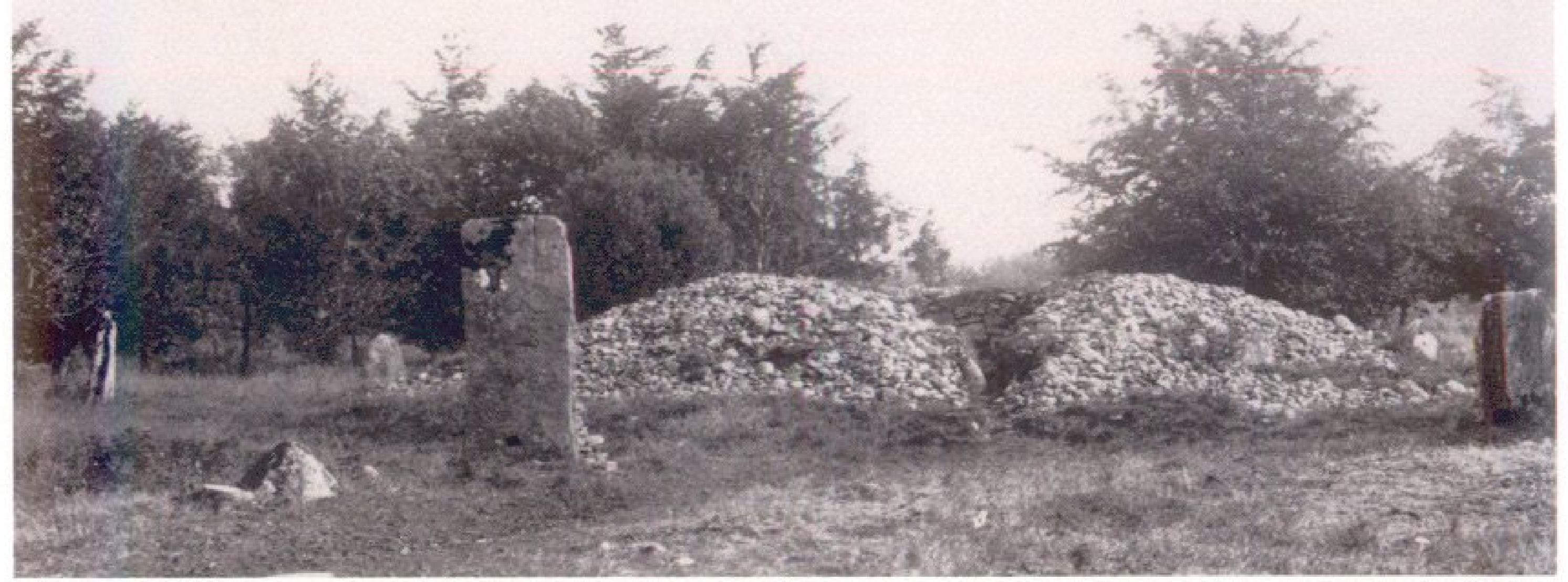

ILLus 8 The north-east cairn in 1930/1 (NMRS no A48004). Some clearing has taken place but the kerb is still hardly visible

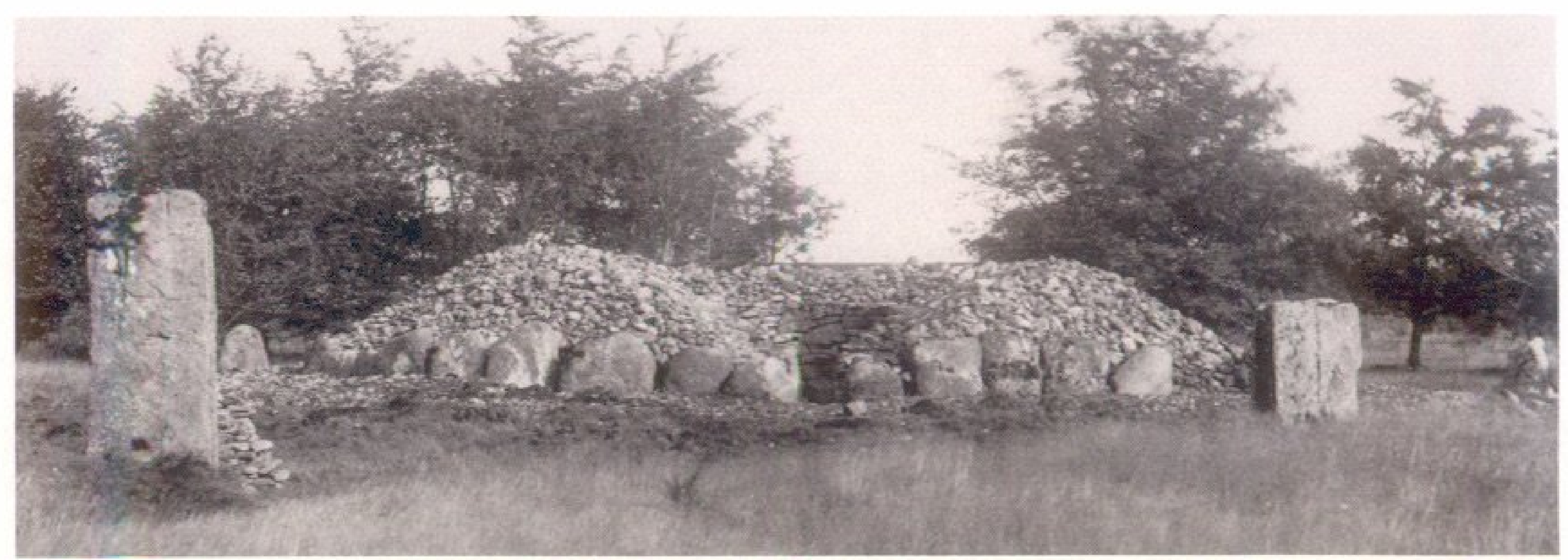

ILLUS 9 The north-east cairn in 1931 (NMRS no A48018). The cairn has been cleared and the kerb has been exposed by removing some of the ramp 


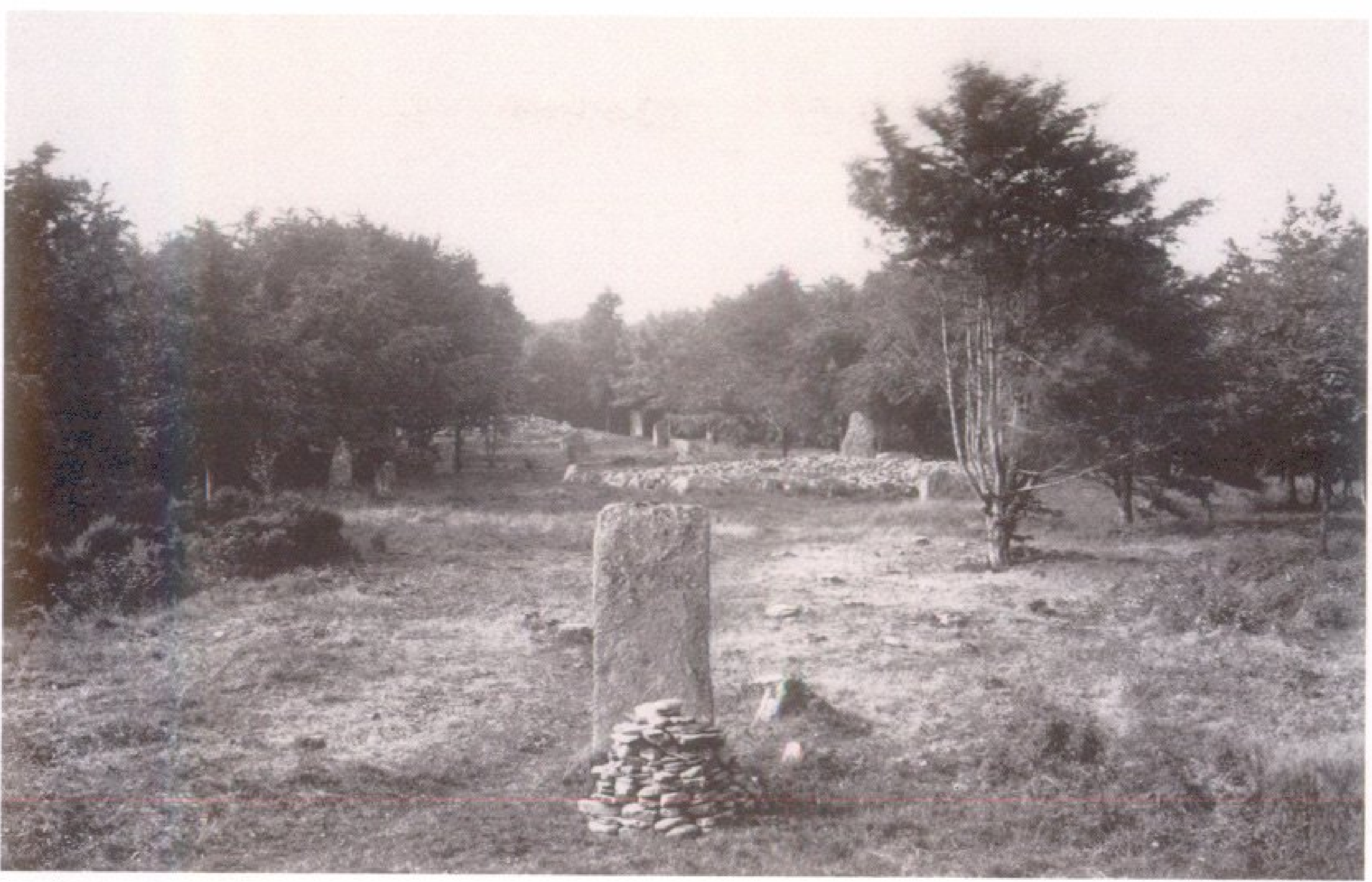

ILLUS 10 Balnuaran from the north-east cairn looking towards the south-west cairn, 1930 or 1931 (NMRS no A48003)

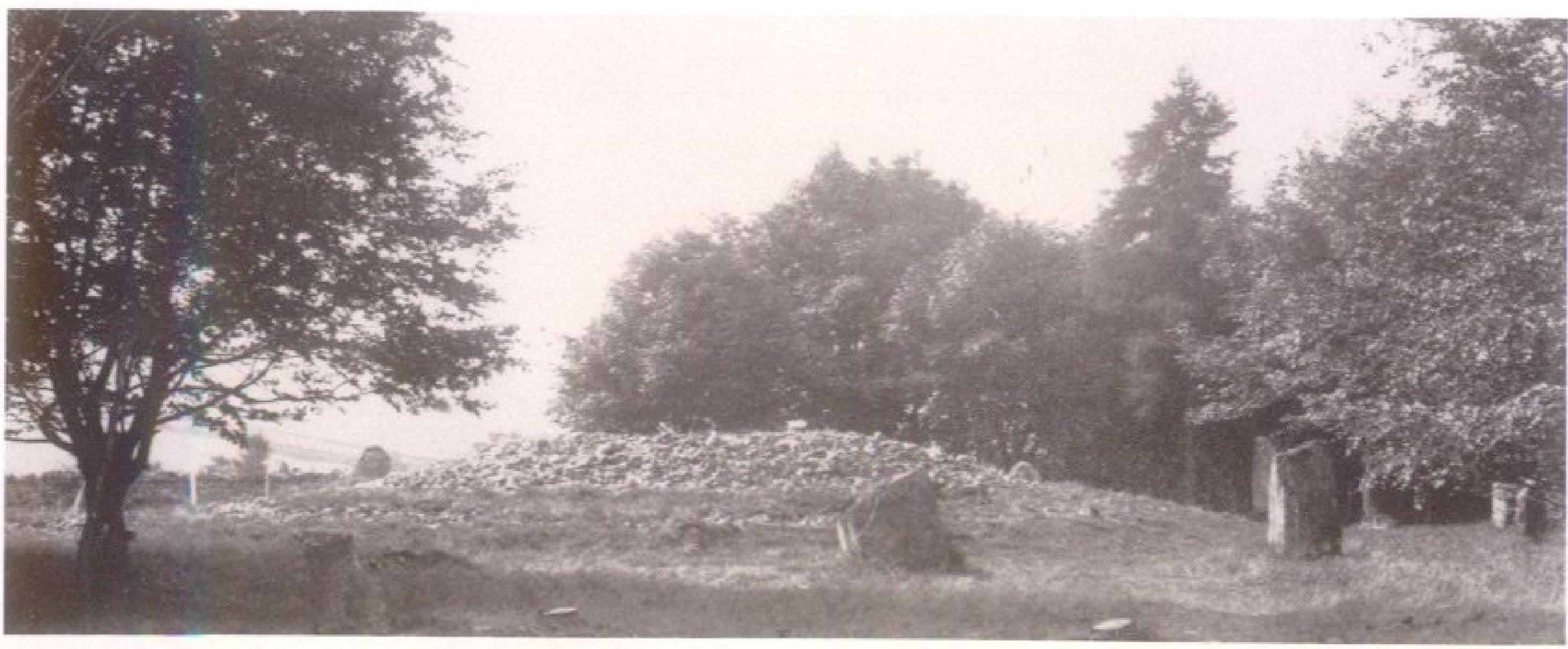

ILlus 11 Balnuaran south-west before the kerb was exposed, 1930 or 1931 (NMRS no A48010) 


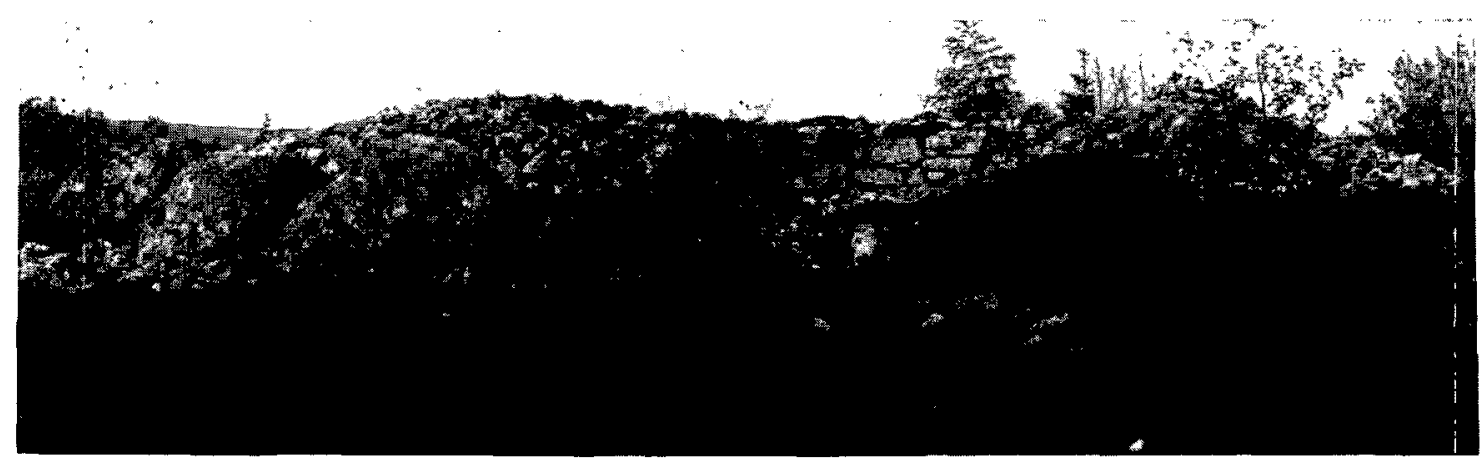

ILLUS 12 The south-west cairn in 1924 (NMRS no A47997)

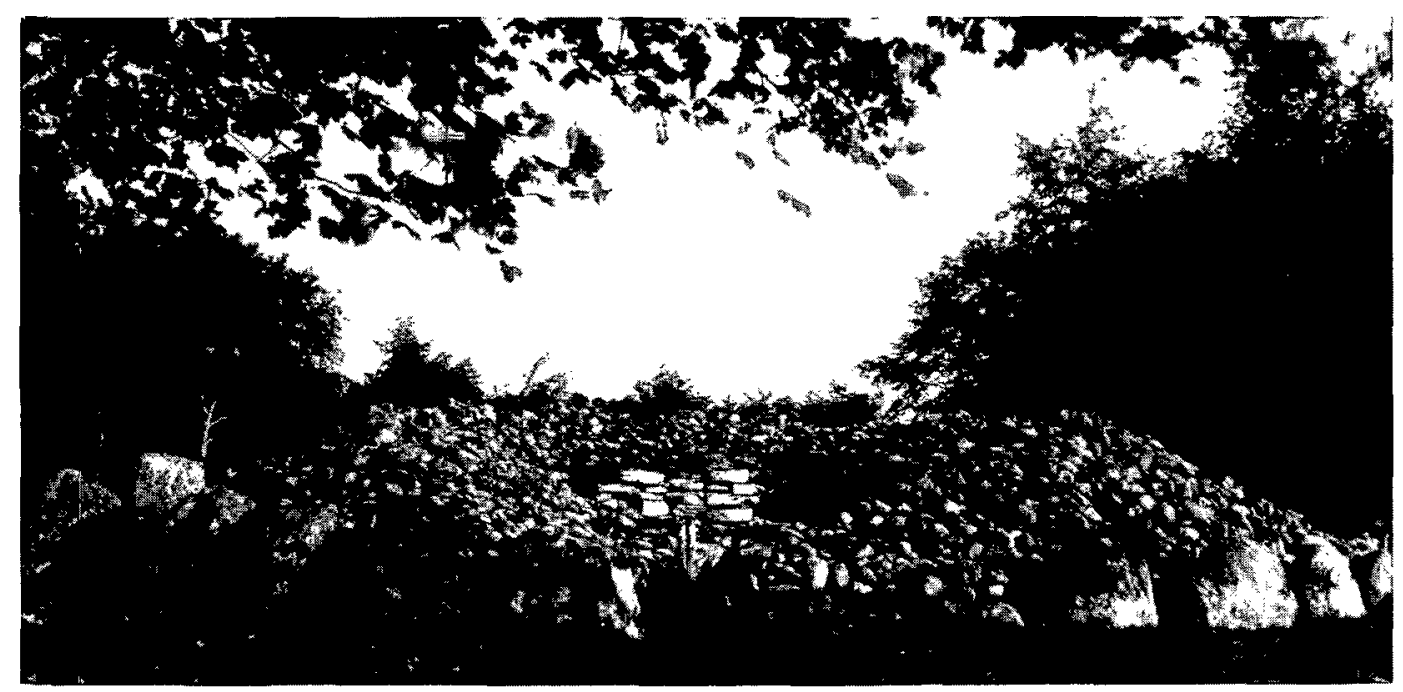

Illus 13 The south-west cairn in 1931 (NMRS no A48019)

\section{NEW WORK AND OUR UNDERSTANDING OF THE CLAVA CAIRNS}

Since the last, and most thorough, study of the Clava cairns (Henshall 1963) there have been a number of developments which have changed certain aspects of our understanding of the cairns at Balnuaran and nearby in the Nairn valley and, to a lesser extent, the rest of the group.

The reports on the work undertaken by Miss Kennedy were not available to Miss Henshall; they add considerably to our understanding of the two chambered cairns, though not of the ring-cairn. In particular the excavation of sections out from the kerbs of the passage-graves and Miss Kennedy's comments on the re-erection of the kerb stones prompts this author to suggest that the role of the material piled against the outer edge of the kerbs may be open to a different interpretation to that put forward by Piggott and Henshall. Henshall (1963; 23) suggested that for the passage-graves in general, the ramp outside the kerb had the function of keeping the kerb stones in place.

Miss Kennedy notes that she was digging recumbent kerb stones out from under this material; the evidence of the annotations on HBM drawing 474/074/15 shows that 20 out of 47 numbered 
stones in the kerb of the north-east cairn were recumbent. It may therefore be suggested that the erection of the outer banking was a separate episode in the history of this cairn, post-dating the collapse of some of the kerb stones which had presumably been inadequately bedded. At Corrimony (Piggott 1956) the kerb stones had been forced outwards by the weight of the cairn material around most of the circumference of the cairn: the published section (ibid, fig 3, section A-B) shows one stone recumbent below the ramp material. It may be that much of the observed displacement of kerb stones occurred after the ramp had been erected, although some stones at least had fallen before it was built, as at Balnuaran.

Miss Kennedy's account suggests that the ramp was made up of two distinct materials: stone of similar size to the cairn material and smaller stones (grading to larger near the outer edge) mixed with shells and soil. The Balnuaran cairns show most clearly the blocking of the entrance by this ramp of material; at Corrimony Piggott suggested that the gap in the ramp in front of the entrance had been filled in as part of the closing of the tomb. It might be suggested though that the erection of the stone bank as a whole was part of the closing of the cairn, especially as the cairns often survive with the kerbstones largely hidden from view. The results of Miss Kennedy's investigations indicate only that there were two distinct materials in the ramps, not how the upper, generally larger stone had got there (illus $14 \& 15$ ).

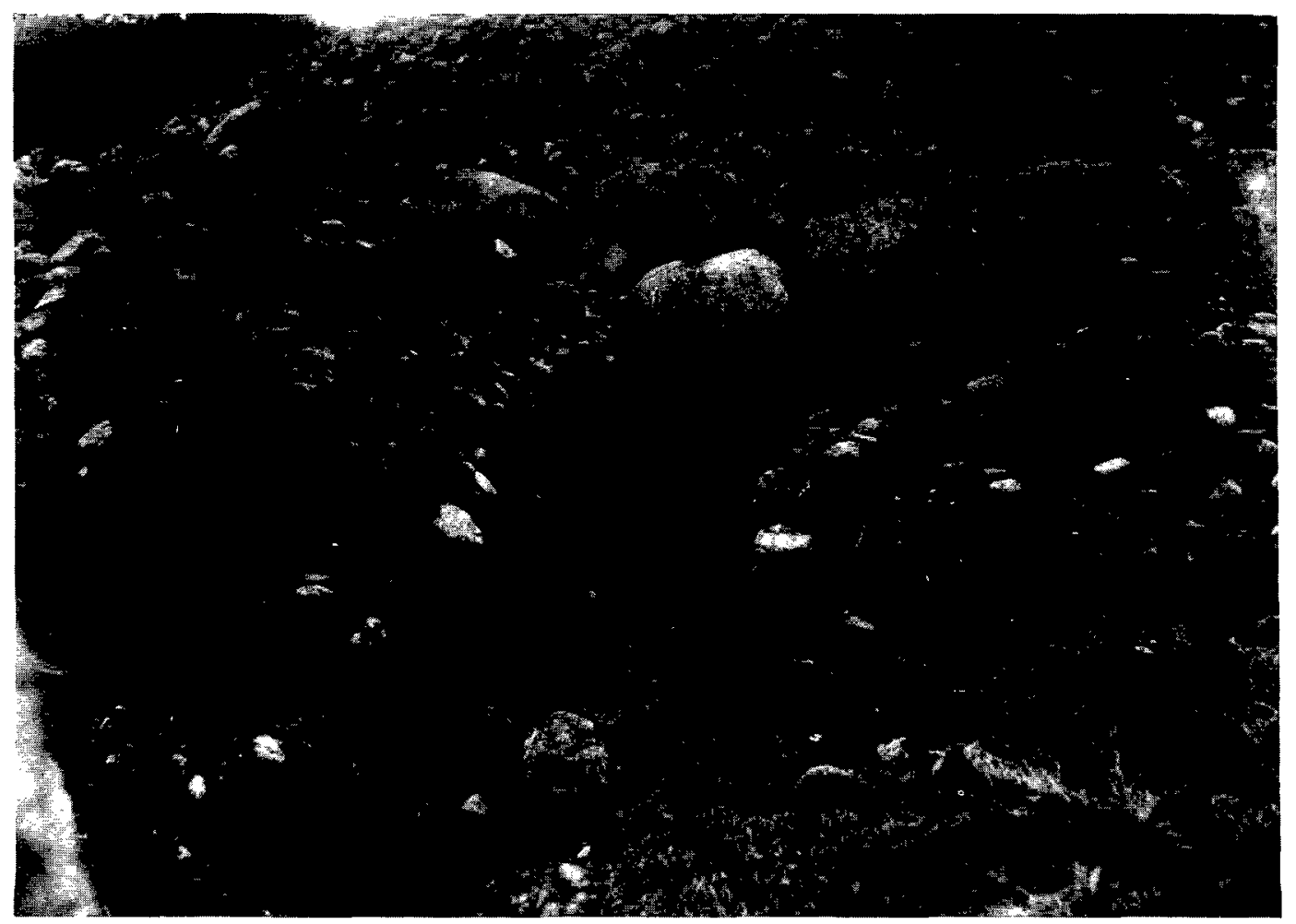

ILlus 14 Miss Kennedy's section through the ramp of the north-east cairn (NMRS no A48023) 


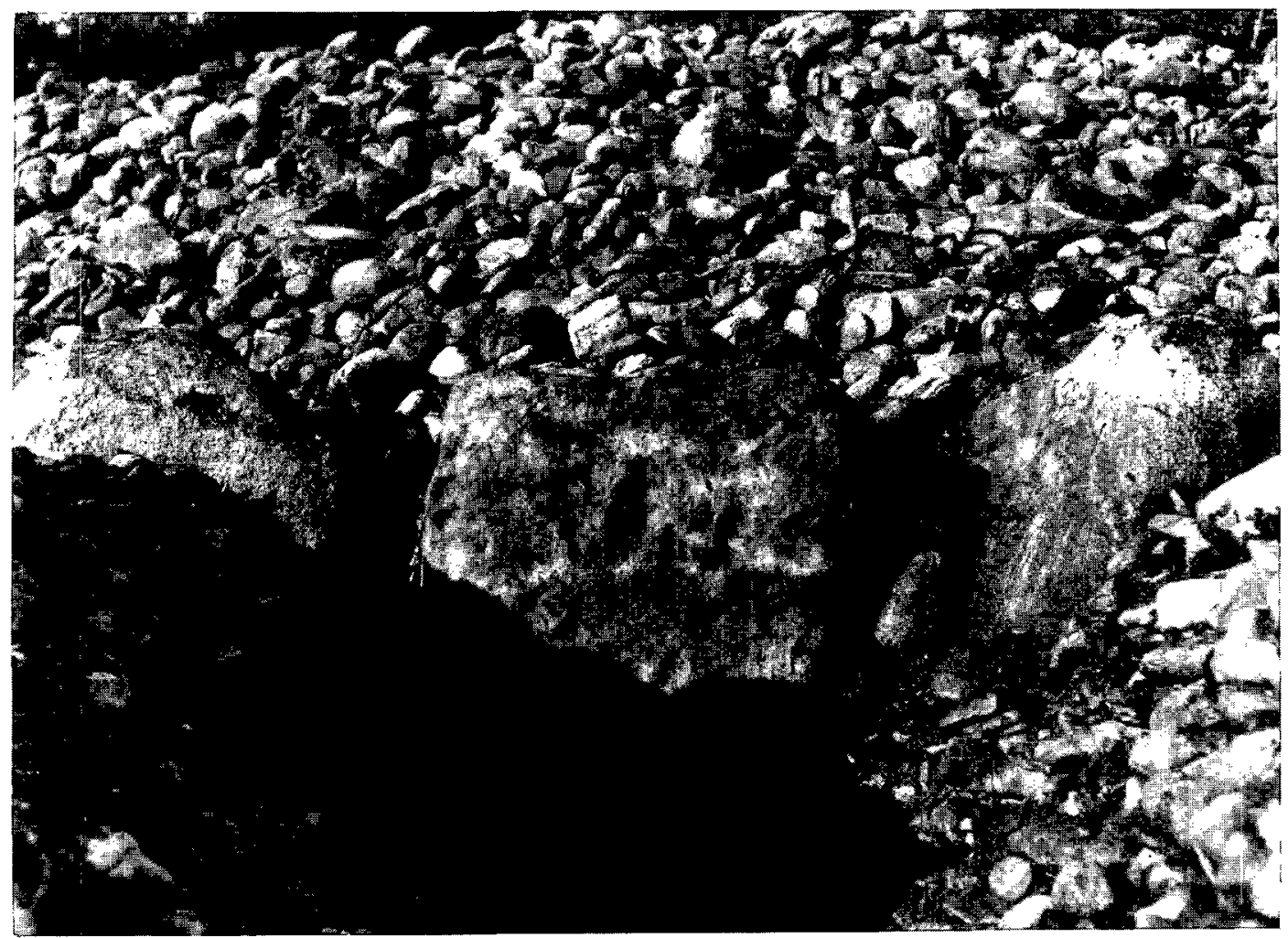

ILlus 15 Miss Kennedy's section through the ramp of the south-west cairn, showing one of the cup-marked stones (NMRS no A48026)

\section{DISCUSSION}

At the time of Henshall's survey of the material, the tombs in the valley of the Nairn were seen as isolated survivors of a prehistoric landscape of which nothing remained. Barber's work at Culdoich (1982), a Clava ring-cairn less than $1 \mathrm{~km}$ to the south-west of Balnuaran, revealed that remains of prehistoric agricultural activity and, presumably, settlement, were preserved below $0.5 \mathrm{~m}$ to $0.8 \mathrm{~m}$ of soil which had accumulated through hillwash and flood. It may be that much of the contemporary settlement pattern related to the Clava cairns in the valley may survive over a large part of the flood plain of the Nairn.

Recent fieldwork has also revealed further visible archaeology in the vicinity of three Clava cairns. Between Culdoich and Balnuaran are the remains of a further Clava cairn (Ballaggan), next to a supposed chapel site (both the cairn and chapel are in the care of the Secretary of State). A recent visit revealed the presence of what appears to be a substantial earthen round barrow only $30 \mathrm{~m}$ from the chapel site, in an arable field. Recent deep ploughing brought a quantity of stone to the surface.

At Corrimony Ms Jill Harden (pers comm) has discovered a substantial round mound, on the scale of some of the larger Perthshire examples (Coles \& Simpson 1965) c $200 \mathrm{~m}$ from the Clava tomb.

For an interpretation of these mounds we can perhaps look to the south, in Perthshire. There, three burial mounds with a complex construction history have been excavated in the last 25 years; 
these round mounds were being built in the area for at least 1000 years (Coles \& Simpson 1965; Barclay 1983; Mercer 1989), and the excavators of Pitnacree and North Mains have both looked to the Clava passage-graves and ring-cairns for parallels, as well as to the ring-cairn tradition of northeast Scotland.

It has been argued that many ceremonial and burial monuments of the Neolithic and Bronze Age are the product over time of the combination of a range of design features (Kinnes 1979, 46; Burgess 1980, 296; Mercer 1981, 154-5; Barclay 1989, 231). Some of these features might only be available in a restricted area at any particular time and the choice of features, the combinations in which they might be used, and the order in which they might appear on a site might depend on regional traditions. The study of henges, for example, has particularly suffered from the difficulties of attempting to fit into a single classification such typical structural features as stone circles, timber circles and burials, all of which also appear alone and in other combinations (Burl 1969; Clare 1986). There are dangers in considering combinations of features as representing the development of unitary monuments; such an approach may lead us away from an appreciation of the changing nature of complex monuments, and the relationships of a number of monuments over time, as new features are added to or replace those already there.

The Pitnacree and North Mains mounds share a phase as a ring-bank surrounding an open space, with a formal access through the bank (a roofed passage at Pitnacree, an access bay at North Mains). These sites and the ring-cairn at Skatewan were completed, from sites enclosing an open space, into regular round mounds. This characteristic is shared with the Clava ring-cairns and with ring-cairns elsewhere in Britain, where the central space is filled to form a near flat-topped cairn (Ritchie \& MacLaren 1972). It may be suggested that the newly discovered round mounds found in the Inverness area might also be complex multi-period structures perhaps incorporating this design development from enclosed space into closed mound. It is interesting to note the contrast between the closing of an immediately accessible space, as at North Mains, Pitnacree and the Clava passagegraves, and the closing of a space practically accessible but with no formal access, as at some Clava ring-cairns, Skatewan (Mercer 1989), Balfarg (Barclay 1983) and at other ring-cairns.

\section{CONCLUSIONS}

Miss Kennedy's work in 1930 and 1931, although conducted on a small scale, has proved to be of considerable value to modern research, at a time when our understanding of the nature and context of the Clava cairns and the prehistoric landscape in which they are set is developing. However, the contents of the file reveal that the familiar characteristics of the cairns at Balnuaran, especially the two chambered tombs, are to an extent the result of the Office of Works campaigns of 1930 and 1931 and the interpretation put on certain features at that time.

\section{ACKNOWLEDGEMENTS}

I am grateful to Myra Tolan, David Breeze, Lesley Macinnes, Audrey Henshall and Graham Ritchie for reading and commenting on the text, and to the HBM photographic section and Lesley Ferguson of the National Monuments Record for help with the illustrations.

\section{REFERENCES}

Barclay, G J 1983 'Sites of the third millennium bc to the first millennium ad at North Mains, Strathallan, Perthshire', Proc Soc Antiq Scot, 113 (1983), 122-281. 
Barclay, G J 1989 'Henge Monuments: reappraisal or reductionism?', Proc Prehist Soc, 55 (1989), 260-2.

Burgess, C 1980 The Age of Stonehenge. London.

Burl, H A W 1969 'Henges: internal features and regional groups', Archaeol J, 126 (1969), 1-28.

Clare, T 1986 'Towards a reappraisal of henge monuments', Proc Prehist Soc, 52 (1986), 281-316.

Coles, J M \& Simpson, D D A 1965 'The excavation of a Neolithic round barrow at Pitnacree, Perthshire, Scotland', Proc Prehist Soc, 31 (1965), 34-57.

Henshall, Audrey S 1963 The Chambered Tombs of Scotland, vol 1. Edinburgh.

Innes, C 1860 'Notice of a tomb on the hill of Roseisle, Morayshire, recently opened; also of the chambered cairns and stone circles at Clava, on Nairnside', Proc Soc Antiq Scot, 3 (1857-60), 46-50.

Kinnes, I 1979 Round Barrows and Ring-Ditches in the British Neolithic. London. (=Brit Mus Occas Pap, 7.)

Mercer, R 1981 'The excavation of a late neolithic henge-type enclosure at Balfarg, Markinch, Fife, Scotland', Proc Soc Antiq Scot, 111 (1981), 63-171.

Mercer, R J 1989 'Skatewan', in The University of Edinburgh, Department of Archaeology Annual Report, $1989, \mathrm{xx}$.

Piggott, S 1956 'Excavations in passage graves and ring cairns of the Clava group, 1952-3', Proc Soc Antiq Scot, 88 (1954-6), 173-207.

Ritchie, J N G \& MacLaren, A 1972 'Ring-cairns and related monuments in Scotland', Scot Archaeol Forum, 4 (1972), 1-17.

This report is published with the aid of a grant

from the Historic Buildings and Monuments Directorate (SDD) 